\title{
The Implementations Of Islamic Law And Post-Conflict Development In Aceh, Northern Indonesia
}

\author{
Adhi Cahya Fahadayna \\ Northeastern University, Global Studies and International Relations \\ Boston, MA, USA \\ fahadayna@gmail.com
}

\begin{abstract}
This topic will focus on how the religion could influence the post-conflict development in Aceh, Northern Indonesia. It will discuss the position and potency of religion in the conflict resolution with analysis how successful religion could stop the Aceh Conflict and bring peace to Acehnese people. This paper also will measure how important religion toward peacebuilding in Aceh. Moreover, this paper will explain the problem behind the Acehnese implementation sharia law and clash between societies that stimulated by the sharia law. This article uses secondary data that acquired from books and scholarly journals. This article also implementscase study in which will analyzes thecase of data that acquired from the research.
\end{abstract}

Keywords: Aceh, religion, conflict, post-conflict development, and Islam.

\section{INTRODUCTION}

Aceh is the only province in Indonesia that has already implemented sharia law. Historically, Aceh is the first place where Islam spread and developed in Indonesia eight centuries ago. 12th centuries ago, Aceh was the center of Islamic civilization, and there was the oldest Islamic kingdom in Indonesia ever existed [1]. Islam is the most important aspect that shaped tradition, culture, and customs in Aceh. Islam has been incorporated into the Acehnese life, the point is Islam and Aceh has experienced cultural assimilation and acculturation. In the contemporary context, Aceh is called as 'Serambi Mekkah' or Veranda of Mecca. That name is used to describe the powerful Islamic influence in Aceh. Nowadays, the Provincial Government of Aceh implements Sharia law as the fundamental law in Aceh as the consequence of conflict resolution between Free Aceh Movement ((FAM)) and the Indonesian government. The provincial government of Aceh also desires to develop the current Islamic sharia with criminal code and capital punishment. Recently, the Qanun Jinayat or Islamic criminal code has been passed into Acehnese parliamentary [2]. The law will be examined by the member of parliament, which consists of parliament members of Aceh and representatives from all of the regions in Aceh. Furthermore, the local government such as Municipalities and Regencies around the Aceh Province have installed the local regulation following the style of Sharia law.

The Aceh conflict was one of the conflicts that happen in Indonesia caused by the clash of the political system between local communities with the national government. The Aceh Conflict occurred in the context of political system discrepancy rooted in the democratization of Indonesia. The discrepancy in Aceh led to insurgency in Aceh in 1976 [3]. Several Acehnese public figures initiated the insurgency war against the Indonesian government. The Indonesian political system is mainly democratic, and it could be identified by the implementation of the essential aspect of the democratic system like pluralism and secularism. In consequence, implementation of the democracy, Indonesia tends to become a secular and pluralist state that could not set religions as the fundamental basis of the Constitution. The system discrepancy between national government and Aceh tradition and culture become the critical cause of the Aceh insurgency in 1976. On the side of a coin, Indonesia also admitted that religion is the part of national identity through several supporting points in the constitution, which collided characteristics of democracy and turned Indonesia into the ambiguous country concerning the relationship between religion and politics [4]. Indonesia guaranteed the citizen freedom of religion and freedom to worship. Nevertheless, the tendency of Indonesian society is Muslim as the majority religion in Indonesia, and several religious minority groups could be affected by the implementation such law.

Aceh in the context of Muslim majorities province has become the strictest province with regards to the implementation of the religious law. During the Insurgency, the prominent organization that becomes the main actor was (FAM) [5]. The purposes of the (FAM) are to make Aceh as an independent state and firmly implemented Islamic sharia. However, recent studies show that (FAM) had a problematic platform about Islam as the core motivation of uprising; it could be identified that the real reason of insurgency was the economic factors, especially the economic disparity between Acehnese and immigrants who lived in Aceh. Moreover, the identity difference among indigenous people of Aceh and immigrants also become great potency of conflict. The Acehnese people believed that Acehnese culture is mainly derived and based on Islam [6], even though several experts argued that. The argument relies on the several cultural experts that emphasize on acculturation and assimilation bet endemic culture of Aceh and Islam. Consequently, Islam is incorporated into the Acehnese culture, but Islam did not entirely change the Acehnese culture. The conflicting identities of Acehnese and Indonesian national identity also contribute to the development of Aceh conflict.

The terrible natural disaster happened in 2004 that killed 220.000 people [7]. The disaster was a tsunami or seismic sea wave that occurred only half an hour in Aceh, but the implication was awful. The tsunami destroyed Acehnese infrastructure and stopped the economic and political activity 
for couple months. The tsunami gave the momentum to the Indonesian government to conduct peace negotiation with (FAM). The negotiations were taken place in 2005 in the Finland. The negotiations urged the Indonesian government to give Aceh a special autonomy, which made a possibility of the implementation of Sharia law. The Sharia law tends to become the only essential point for peace to make the Aceh posttsunami program could go properly [8]. The government recognized Sharia law as the aspect that makes the peace process less complex. Unfortunately, the Acehnese people do not ready to such a Sharia law, because the society in Aceh experienced the modernity and enjoying the democracy for a long time. The significant change of fundamental law in Aceh could cause public confusion because there is no such Sharia law ever existed before.

\section{FRAMEWORK}

\section{A. Thesis Statement}

The crucial inspiration of this paper is coming from recent development in the peacemaking and peacebuilding. Religion has an important aspect in the peacebuilding effort in Aceh [9]. Besides the public debates among the Aceh society regarding the implementation of Sharia law, Acehnese culture has been incorporated into religion for a long time. As the significant contribution toward peacebuilding effort in Aceh, religion also contributes restoration of Aceh in a proper manner and effective effort. However, the consequences also contributing a new problem in the future, in this token religion is attributed with conservatism that could cause collision within the contemporary context of Acehnese society. Furthermore, Aceh is one of the Indonesian provinces that experiencing modernization similar to any other regions in Indonesia. The Aceh society is majority Muslim, but the socio-cultural landscape shows that most of the Acehnese people are unorthodox and implementing a modern Islamic teaching. Regarding the Acehnese modernization, Islam in Aceh has turned to become more contemporary, adopt the current situation and preserves flexibility within societal life, such as dress code, social activity, and lifestyle. Towards identification of the different phenomenon in Aceh, implementation of Sharia law could be seen as the positive outcome for peacebuilding in Aceh. However, the ramification also could cause the public confusion and unpreparedness to obey the law.

\section{B. Literature Review}

Aceh conflict has been waging in Indonesia since the beginning of Netherlands Colonialism in Indonesia. Aceh was the first Islamic State that had the biggest pepper commodity in Southeast Asia at that time. The Kingdom of Netherlands was aware that Aceh is one of crucial potency for ensuring economic stability for Netherlands Colonialism in Southeast Asia. By the end of 19th century, Netherlands launched several military campaigns to dominate and control Aceh territory and its resource [10]. Surprisingly, Netherlands army faced tremendous resistance from Acehnese people and Aceh Islamic Sultanate, in which could hinder the Netherlands interest in pursuing its colonialist agenda. Netherlands military faced unimaginable resistance from Acehnese, and it contributed massive loss toward Netherlands military campaign also contributing huge military expenses. The Acehnese resistance is one of the most powerful resistance toward Netherlands colonialism before the independence of Indonesia. Even though the Acehnese resistance was in the local scope and it had not involved national resistance toward colonialism, the inspiration from the Acehnese resistance become the main inspiration to defend the independence of Indonesia against the Netherlands colonialism. Consequently, many historians agree that the Acehnese has embodied the constant rejection toward all form of colonialism and particularly domination of its freedom. Even after the Indonesian independence in 1945, the quest for Acehnese independence is never stopped. Acehnese still waging ongoing resistance toward the government of Indonesia, that has been seen as a new form of colonialism. The conflict between the Indonesian government and Acehnese resistance groups could be postponed in 2005, after the intense negotiation that concluded to give Aceh full autonomy also implemented Sharia law. The development of Aceh resistance toward political domination and colonialism could be traced during the 16th century. When the Kingdom Portugal successfully conquered the Sultanate of Samudra Pasai in 1521, Acehnese had fought the army of the occupation to restore their freedom and independence [11].

Even after the invasion of the Kingdom of Netherlands in the 19th century, the battle for Acehnese independence was not yielded at all [12]. In the recent development, Acehnese has been continuously involved in the conflict since the 1950s until 2005. The Aceh conflict has lasted for a long time and become the longest conflict that ever happened since the Indonesian independence in 1945. The rationale behind the longstanding conflict merely about the historical and cultural value that emphasizes the spirit of freedom and independence. Therefore, every domination that surpasses the freedom and independence of Aceh will cause conflict, including the contemporary Indonesian political system. With the robust influence of Islam in the Acehnese culture, all aspects of Acehnese people live will be following the religious teachings, such as the lifestyle, culture, local norms and customs even the local laws and regulations. Within the identity of Acehnese people, Islam becomes the crucial part of the identity of Acehnese people in which already embodied through generations. Subsequently, within the scope of people identity could inspire the systemic aspect in which will automatically follow the Islamic theology and teachings. In the current context, the implementation of Sharia law as the most fundamental value in the politics, leadership and basic law also cultural customs coherent with Acehnese identity [13]. In consequence, any objection or rejection by the central government or national regulations will trigger the conflict.

Current studies highlight the role of religion as a 'doubleedged sword,' which means that besides the role of religion as the source of conflict, on the other side of the coin, religion also regarded as the source of conflict [14]. Scholarly works have indicated that throughout the emergence of violence under the banner of religion, religious extremism, radicalism, and terrorism become fundamental basis that supported the argument of religion as the inspiration for conflict. In the context of Aceh, religion could be seen in a positive way in which that religion becomes a practical aspect that promotes 
peacemaking and peacebuilding in Aceh, even sustainably appear in the post-conflict development. For explaining the role of religion in the conflict resolution, particularly in the peacemaking and peacebuilding also post-conflict development, we will discuss several crucial points that are accentuating the role of religion in the conflict resolution. First, the notion of religious peacemakers, in particular, religious leader and religious peacemaker in the conflict resolution [15]. The role of religious peacemaker explained the religious motivation or religious calling that motivate religious peacemakers to engage in the conflict. The aspects that made religious peacemakers devoted engaging in a conflict is the most crucial indicator to sustain the rationale of religion as the source of peace. Furthermore, the sources and potencies that religious peacemakers have to engage in the conflict also become important indicators to assess to what extent religion involved in every step and procedures of conflict resolution. Another aspect that could not be undermined is the religious teaching. Religious teachings also become the theological basis for religious peacemakers to involve in the conflict, also become the divine inspiration for actors and perpetrators of the conflict to acknowledge reconciliation and peace. The emergence of religious peacemakers is the most intriguing phenomena in the current development of the study of peace and conflict resolutions.

Religion is not only about one thing. Certainly, religion is consisting many aspects that necessary for human life. Religious movement and activism are several examples that religion could contribute to the responding the social problem. Religious activism and movement have always been inspired by the altruism of religion, which is derived from the divine enlightenment that exhibits godly and ideal lessons on how people should live life their life. Hence, the second point is the crucial element of religious activism and movement also the public image of religion [16]. Commonly, the religious organization becomes the best example for describing the role of religious movement and activism. Religion is a global entity, which means religion developed and spread throughout the world regardless cultural, social and political difference. The religious organization often established as a non-governmental and intergovernmental organization, through those establishments, religion could provide their international network and massive potency to encourage such conflict resolution. The religious organization also popularly have a positive view because of the easiness to reach actor of the conflict, especially when a conflict involved similar religious affiliation.

Another aspect that becomes very crucial in the conflict resolution is a dialog. Only dialog that could bring all actors, stakeholders, and mediator together to discuss the conflict and its possible solutions. Interfaith dialog is the variant of the dialog that could be implemented toward the conflict that involves religious actors and aspects. Through interfaith dialog, all religious actors and conflicting actors could apprehend and absorb religious teachings that focused on the peace and coexistence [17]. Additionally, through interfaith dialog, religious peacemakers could build a conflict resolution framework and make all aspect of the religion to the common ground of peace and coexistence. Religious peacemakers would utilize the network and massive resource to conduct conflict resolution as short as possible. In the conflict that involving religious actors and religious aspect, the role of dialog become more important than other. Usually, religious peacemakers are free from intervention or at the complex situation only minimum interaction with stakeholders and actors of the conflict. Minimum intervention is the ideal situation to conduct religious peacemaking and peacebuilding. However, it does not automatically make the conflict easier to resolve. Minimum intervention in the conflict resolution contributes positive aspect of reconciliation, especially maintain neutrality and legitimation of peacemakers. Therefore, peacemakers could work without any burden that could hinder reconciliation.

Discussing religion in the conflict resolution must be followed by the study of religious text and its theology. It is mandatory to seek the religious justification of peace and coexistence within the religious tradition. This process required to establish the certain aspect of religion that could encourage peace initiative from the conflicting environment [18]. Without a study of religious text and theology will be very difficult to implement religious peacemaking and peacebuilding. The strongest legal and theological justification in religious life only came from the religious text. It is specifically defined how the people should live the life. In the most extreme conflict, this method regarded as the most complicated and contentious method. The implication of studying religious text and theology in the context of conflict could turn the actors of conflicts become more radical and extreme. However, many experts believe that through the study of text and theology, conflicting societies will have more sophisticated and comprehensive understanding of their religion. Thus, it is possible to find a solution to a conflict when they learn that violence and conflict are lack of religious justification. Most important reason to bring theology and religious text is about educating people, and it becomes crucial because people need to have a more sophisticated understanding of their religion. It became core value to call upon realization of coexistence and pluralism among conflicting societies. Building the foundation of coexistence and pluralism will lead the way of reconciliation that will develop to peace-building actions. Bringing religion to the conflict would not cause more complicated stages of the conflict, in contrast, it will lead people to reconsider the source of conflict and its relationship with their religion. It cannot be said that in general religious conflict should be separated from religion, on the other hand, religion could become effective tools for restoring peace and build the reconciliation. In some cases, the conflict that initiated by religion involved some misunderstanding about the theology and religious text. Consequently, religious peacemakers demanded to clarify and correct those misunderstandings.

In conclusion, there are two theses about religion and peacemaking, and both are contradicting each other. Religion is a double-edged sword that could lead the conflict escalating uncontrollably. However, there are several cases shows that religion in some cases effectively works on resolving the conflict. Principally, religion is not a popular aspect of the conflict resolution, it always considered as the source of conflict. Also, escalation of the role of religion in conflict 
resolution purely a new phenomenon. We could not dispute the extent to which religious leaders engage in the peacebuilding and peacemaking, also the role of faith-based organizations and other religious, humanitarian missions. The realization of religion in the peacebuilding and peacemaking is towards several activities has been proven effective and working. Such as how the conflicting societies could engage in the interfaith dialog and social activities that hosted by a religious institution. More importantly, the religious leaders networking towards stake holders or local leader, it will become the tremendous strength for the religious leader to handle conflict resolution. Naturally, religion will not agree with conflict by all mean, and it will oppose any conflict and violence. However, there is a gap that allows religion give justification to the conflict. When conflict happened, the aid from religious organizations will come early compare to other organizations [19]. Religions could overcome any obstacle that might discourage other peacemakers to engage in the conflict. Religions are not a common enemy, and the people easily accept the universal teachings of religions

\section{The SHARIA POLITICS AND ISLAMIC LAW IN ACEH}

Up to now, Aceh nationalism is the central concept that motivates the struggle for independence of Aceh [20]. Aceh nationalism requires the creation of a new country that separated from the current political entities. The country has to have independent status in which become the primary objective of the movement that based on the Aceh nationalism

The country must be formulated on the central idea of Aceh nationalism. Therefore, it will represent a spirit of Acehnese culture and traditions. Therefore, Acehnese will implement the law and political system that coherent with the Acehnese culture and tradition. Islam is one of the important aspects that could not be separated from the Acehnese, and Islam is the core of Acehnese culture. It is clear that Islam has already incorporated to the Acehnese live and culture since a couple of centuries ago. The creation of Acehnese state has followed by the implementation of Islamic law as the foundation of the state itself. As consideration, the first political entity that exists in Aceh was the Islamic Sultanate of Samudra Pasai. This kingdom was predominant Islamic political entity in Indonesia, from this kingdom, Islam spread around Indonesia. The golden age of the Islamic Kingdom in Aceh became the inspiration for Aceh nationalism in which stimulate the willingness to reinstate the Islamic state after the independence of Indonesia. Mostly Acehnese leaders during the early independence of Indonesia consider Indonesia had not accommodated the Acehnese nationalism [21]. Therefore, the rebellion against the government of Indonesia had been justified in this manner. Acehnese demanded the government of Indonesia to acquire such as a system that allows Aceh nationalism and Islam to be implemented by all means.

The complexity of Indonesian political system would not allow that inside one state there are two different political system exist. Indonesia has six official religions, and implementation of Islamic political system will damage the spirit of multiculturalism. The ramification of this complexity was the longstanding conflict between the government and the
Acehnese people who want to make Aceh as an independent state. The initial rebellion against the government of Indonesia was started in the 1950 s by Teuku Daud Beureueh, an Acehnese politician and charismatic Islamic scholar [22]. He proclaimed the creation of Islamic State of Indonesia (ISI) that will be accommodated Acehnese interest. Daud Beureueh pointed out that the Indonesian government was never suitable for the Acehnese culture, he added more that Indonesia would not make Acehnese people prosper [23]. At that time, the government of Indonesia focused on the centralization of government and built the capital city for better administration for a newborn state. This policy stimulated disappointment among Acehnese people and leaders because the government should distribute the development equally throughout the country and not only focused on the capital city. The unequal development and devastating economic condition motivated several Acehnese leaders like Daud Beureueh to rebel against the government.

The rebellion of Daud Beureueh apparently could be eliminated by the Indonesian Army. However, the sustainer of Daud Beureueh's ISI still exists in the Aceh rural area. The fighters of ISI had conducted a guerrilla war against the Indonesia government until 1962. The rebellion ended by a peace agreement between the Indonesian government and remaining ISI leaders. Nonetheless, Aceh Nationalism never died, it still motivated former ISI fighters and ISI leaders who disagree with the peace agreement in 1962 to rebel against the government. The rebellion reinitiated again in 1976 by remaining leaders of ISI, such as Hasan di Tiro, Zaini Abdullah and so forth [24]. These leaders are also motivated by economic interests besides Aceh Nationalism. The reason for rebellion again driven by the unequal development and uneven distribution of wealth. The new rebellion formed the military guerilla and called Free Aceh Movement (FAM). The Aceh conflict is the longest rebellion movement that is conducting an insurgency against the Indonesian government. The Indonesian Army faced difficulties to fight with Aceh separatists, and it caused by the uncooperative of Acehnese toward Indonesian military. The sympathy toward FAM increase tremendously, and it is because of the vision of FAM to improve the prosperity of Acehnese. The high numbers of casualties and longs standing conflict attracted international concern, mainly because of the never-ending conflict that happened in Aceh soil.

The devastating disaster, tsunami that hit Aceh in 2003 forced Indonesian Army and FAM to form a reconciliation forum and start negotiations as soon as possible. Sweden government facilitated the peace process that happened between Indonesia and FAM, and it formed the Helsinki Accord. The Helsinki Accord was the new momentum for Aceh to move on from the history and starts to focus on the rebuilding Aceh [25]. The government of Indonesia demanded any insurgency must be terminated, also no independence for Aceh by all means. FAM was aware that the Indonesian government would ask that kind of request. The FAM then proposes full autonomy for Aceh in which that provide wider opportunity to implement their political and law platform that derived from the Acehnese culture and freedom to exploit natural resource in Aceh for the prosperity of Acehnese. The 
government of Indonesia agreed with the condition from the FAM and granted such a full autonomy for Aceh [26]. This is the early phase how Indonesian government using sharia law to enforce peace in Aceh.

In the critical approach, the Indonesian government was aware that Acehnese would suspend the idea of creating an independent Acehnese state if they have the opportunity to implement full autonomy and sharia law. Consequently, implementation of sharia law become the strongest alternative for the Indonesian government to avoid Aceh independence. The Indonesian government was also aware that Islam has contributed to strengthening Aceh core identity and culture [27]. The Acehnese separatist group would accept any demands from the government if the autonomy implemented. Accordingly, the government uses the Islamic law as the political aspect to maintain Aceh under the rule of the Indonesian government without releasing Aceh as an independent state. The notion of sharia law is tremendous during negotiation, and its role as the political aspect to fight the insurgency in Aceh had been noticed since the 1950s by the government. The Indonesian government was conscious that the core of Acehnese conflict mainly as unequal development and unequal distribution of wealth. The government could not provide Acehnese with a comprehensive development in a short period. Hence, utilizing sharia law was another solution to pursue complete surrender from the rebellion group [28].

The Acehnese society favors to live under the sharia law and disregard any other problem that might contribute insignificant influence toward Acehnese live itself. Using Sharia law to oppose the idea of Aceh nationalism was a smart strategy because it already answered one of the root-causes of the rebellion against the government and it will gather the positive impression toward the government of Indonesia. Islamic scholar or ulama will support the idea of sharia implementation and promote the national identity that could oppose Aceh nationalism [29]. With the help of ulama, the Indonesian government would get a significant support of the insurgency groups [30]. The Acehnese people have been considering enormous respect to the ulama and consider the opinion of ulama as the religious law or fatwa. This kind of behavior simplifies the propaganda of the Indonesian government against Aceh nationalism. From side to side of the help from ulama, the Indonesian government also success to decrease the influence and appeal of the insurgency groups. The significant religious propaganda toward Aceh has been contributing significant effect toward Indonesian government and help the government to encourage people to preserve Indonesian as their homeland rather than to accept the concept of Aceh nationalism.

The implementation Islamic sharia irrefutably was a massive strategy of the Indonesian government to reduce the influence of Aceh nationalism. It is clear that the sharia law has been used to maintain the power of Indonesian government over Acehnese and decrease the tension with insurgency groups. In the constitutional context, the sharia implementation could be facilitated by the national constitution through the decentralization policy, which is giving opportunities for any provincial governments to conduct their government or in other word giving an autonomy [31]. The politics of decentralization support Aceh provincial government to implement their system and manage their government based on any law that Acehnese wanted. Sharia law is the choice that Acehnese make, and it is such foreseen solution because sharia law has embodied in the Acehnese live for over a century ago. The sharia also success to reduce the conflict in Aceh and helps the reconciliation process more thorough. The former FAM fighters and its leaders could participate in the local election and success to gain a majority position in Aceh. Outstandingly, the conflict between local government and national government reduce immensely after the implementation of sharia law under the local reconfiguration [32].

\section{The Religion, Violence, And Politics on the IMPLEMENTATION OF ISLAMIC LAW IN ACEH}

The peace that expected by Acehnese become problematic. Acehnese must face reality about the change of their law. Aceh, like any other province in Indonesia, has been growing as the multi-ethnic and promote a secular system that derived from the national constitution for decades. Acehnese never experienced such a sharia law that implemented significantly and become fundamental law in which become the foundation of prosecution for any violation. Shockingly, with the growing tendency to abuse the law, yet the local government creates a new and unique agency that responsible for the enforcement of sharia law, called Wilayatul Hisbah (WH) [33]. The implementation of Sharia law tends to focus on the insignificant violation, such as dress code and personal lifestyle. Moreover, the aspect of the enforcement like adultery or khalwat tends to become overlap [34]. The couple that riding a motorcycle together without an official status of marriage on the public space could be prosecuted because of violation of adultery. The law tends to become such an oppression toward Acehnese because of radical change in the habit of Acehnese that experienced modernization in the first place. The law itself based on the reprobate foundation of Islamic law because the implementation was the political agenda rather than become society aspiration, the clash between society and the law is unavoidable [35].

The sharia law has been grown outrageously time by time and started to prohibit ordinary activities that Acehnese did for a long time ago. The most prominent example is a prohibition of celebrating the new year by any activity [36]. The new year celebration considered the non-local tradition and mainly came from the western society. Therefore, the government classified the new year celebration as blasphemy and prohibit any celebration related to it. The society starts to feel uncomfortable with the new phenomenon after implementation of sharia. Society even begins to taunt the WH and tries to ridicule the law by celebrating a new year. Society even does not care if the WH prosecute them because of celebrating the new year. Fortunately, the overwhelming crowds celebrating the new year leave the WH powerless. The massive crowd was passing the WH without any apprehension because they knew that WH also could not sporadically capture the crowd that celebrating the new year.

Another aspect that worth to mention is about the implementation of Sharia often disregards gender 
consideration. The tendency of sharia to violate equality between the gender is tremendously high and consistent [37]. Frequently, women become the most disadvantaged gender in the context of sharia enforcement. Women are always vulnerable in which the implementation of sharia limit the role of women in the society [38]. Women could not get an equal opportunity compared to a man. Furthermore, women could not get an education as good as a man can have. Sharia limits the role of the women in the society because ideally women are manifested on the responsibility for household work. Moreover, in the case of adultery women could easily convict guilty and severe numbers of canning with the man she commits adultery. The women could not defend herself without a minimum number of an eyewitness, which is according to Sharia four witnesses need to provide before the court.

Current Aceh society with the influences of modernizations and globalizations, turn becomes a very modern society. Moreover, many immigrants come from all over Indonesia and settle in the Aceh. The immigrants often have a different religion with the majority of Acehnese, such as Christian Protestantism and Roman Catholicism [39]. These two religions also existed in Aceh because if growing number of immigrants. More churches have built in Aceh, and increasing tension stimulated by the decrease of religious tolerance within society. The Acehnese that living under Sharia law tend to become intolerance and could not allow other religions practice them believe under the sharia law. The new churches that build could easily attack with little provocation from the religious and political leader. The reduce of religious tolerance more likely stimulated by the sharia law and mostly happens in the rural area. The more traditional society which never experienced multi-religious life become vulnerable to conflict.

The public execution is the other issues that become a concern of human rights activist in Aceh. The public canning of those who violated sharia has held routinely in front of the biggest mosque in Aceh, The Grand Mosque of Baiturrahman. The public canning towards violators intended to discourage people from violent the sharia law [40]. The public canning never became popular in the Acehnese society. It is more likely that Acehnese experiences new experience regarding the public canning. The canning also did not primarily represent the local customary and tradition of Acehnese itself. It clear that the canning itself copying the style of Saudi Arabia law. The public canning and public execution are very common in Saudi, but not in Indonesia. The Acehnese seems very reluctant to watch the public canning because the canning punishment intends to ridicule the violators [41]. It is clear that public canning not closely related to the interest of enforcing Acehnese culture.

\section{CONCLUSION}

The actual problems that the Indonesian government conceals were economic justice and equal distribution of wealth. Implementation of sharia apparently reduce the conflict in Aceh, but there is a collateral damage has to pay. Religion success to bring peace toward Acehnese but it clear that Acehnese is not accustomed to the implementation of the religious law. The Acehnese has never experienced the binding and strict law of current sharia law. It is clear that sharia law intends to reduce the conflict and restore order in Aceh. The Acehnese peace process is motivated by the implementation sharia law to make FAM surrender and abide by the government demands. It is clear that peace in Aceh was about the political agenda of the government, but it comes with considerable collateral damage. The government disregards the real problem that Acehnese face, which is economic justice and equal distribution of wealth. Through religion, the government tend to conceal the real issue and makes an excuse for the peace restoration in Aceh.

Clashes between society are unavoidable. The growing tension that stimulated by religious fundamentalism that caused by the implementation of sharia law encourage conflict between Acehnese residents. The conflicts are involving majority Muslims and minority non-Muslims. The Christians are the most affected religion by the implementation of sharia law. The provocation from a religious leader and political leader, Churches in Aceh often attacked by the majority Muslim of Acehnese. Moreover, the tolerance that already embodied in Acehnese culture abridged by the enforcement of sharia. This situation that makes the condition in Aceh become worsens, and the condition of multi-religious lives in Aceh has been threatened.

\section{REFERENCES}

[1] M.C. Ricklefs. A History of Modern Indonesia since c. 1200. CA: Palgrave Macmillan. 2008, pp, 38.

[2] D. Afrianty. Women and Sharia Law in Northern Indonesia: Local Women's NGOs and the Reform of Islamic Law in Aceh . Ox: Routledge, pp, 60.

[3] Ricklefs, A History of Modern Indonesia, pp, 364. Democracy is defined as the system that promotes four fundamental pillars, which are justice, equality, freedom, and representation (See Samuel P. Huntington. 1991. The third wave: democratization in the late twentieth century). In the context of democracy, equality becomes closer to welfare. The economic welfare is one of the most reliable indicators for measuring how democracy implemented in a country. Moreover, the recent study indicated that democracy is about political equality, in which that is giving all equal opportunity and distributive political representation. (see Robert Dahl. 1998. On Democracy). On the contrary, democracy seen as the matter of political representation, it is crucial to implement such comprehensive and equal representation as the fundamental basis of democracy (see Seyla Benhabib. 1996. Democracy and Difference: Contesting the Boundaries of the Political).

[4] Ricklefs, A History of Modern Indonesia, pp, 246

[5] Ricklefs, A History of Modern Indonesia, pp. 364

[6] E. Aspinall. Islam and Nation: separatist rebellion in Aceh, Indonesia. CA: Stanford University Press. 2009, pp, 11.

[7] Ricklefs, A History of Modern Indonesia, pp, 406

[8] Aspinall. Islam and Nation, pp. 211.

[9] S. A. Kadayifci-Orellana. Peacebuilding in the Muslim World. In A. Omer, R. S. Appleby, and D. Little. (Eds.), The Oxford Handbook of Religion, Conflict, and Peacebuilding. 2015. New York: Oxford University Press, pp. 440.

[10] Ricklefs, A History of Modern Indonesia, pp. 176

[11] Ricklefs, A History of Modern Indonesia, pp. 4

[12] Ricklefs, A History of Modern Indonesia, pp. 177

[13] Aspinall. Islam and Nation, pp. 208 
[14] The Tanenbaum Center for Interreligious Understanding. Peacemakers in Action: Profiles of Religion in Conflict Resolution. NY: Cambridge University Press. 2007, pp. 5

[15] S. Appleby \& D. Little. A Moment of Opportunity? The Promise of Religious Peacebuilding in an Era of Religious and Ethnic Conflict. In C. Harold \& S.S, Gordons (Eds.), Religion and Peacebuilding. NY: SUNY Press. 2004, pp. 2

[16] P. Moizes. Peacemaking through interreligious dialogue in Macedonia. In D.R. Smock (Ed.). Religious contributions to peacemaking: When religion brings peace, not war. D.C. : UN Institute of Peace. 2006, pp. 31

[17] The Tanenbaum Center. Peacemakers in Action, pp. 10

[18] D. Little. Religion, Violent Conflict, and Peacemaking in D. Little and The Tanenbaum Center for Interreligious Understanding. (Eds.), Peacemakers in Action: Profiles of Religion in Conflict resolution. 2007. New York: Cambridge University Press, pp. 438-439

[19] R. S. Appleby. (2015). The New Name for Peace? Religion and Development as Partners in Strategic Peacebuilding. In A. Omer, R. S. Appleby and D. Little (Eds.), The Oxford Handbook of Religion, Conflict, and Peacebuilding. 2015. New York: Oxford University Press, pp. 187.

[20] Aspinall. Islam and Nation, pp. 11

[21] Aspinall. Islam and Nation, pp. 12

[22] Aspinall. Islam and Nation, pp. 32

[23] Aspinall. Islam and Nation, pp. 33

[24] Aspinall. Islam and Nation, pp. 39

[25] M. A. Miller. Rebellion and reform in Indonesia: Jakarta's security and autonomy policies in Aceh (Vol. 10). 2008. New York: Routledge, pp, 150.

[26] Miller. Rebellion and reform in Indonesia, pp. 159

[27] Aspinall. Islam and Nation, pp. 11
[28] Aspinall. Islam and Nation, pp. 34

[29] S. J. Barter. "Ulama, the state, \& war: Islamic community leaders in the Aceh conflict." Contemporary Islam 5, no. 1. 2011, pp. 20-21.

[30] Aspinall. Islam and Nation, pp. 37

[31] R. W. Hefner. Shari'a Politics: Islamic Law and Society in the Modern World. 2011. Bloomington: Indiana University Press, pp. 298

[32] Afrianty. Women and Sharia Law in Northern Indonesia, pp. 62

[33] B. Otto and M. J. Otto. Shari'a Police in Banda Aceh: Enforcement of Islam-based Regulations and People's Perceptions. In R. M. Feener, D. Kloos \& A. Samuels. (Eds.), Islam and the Limits of the State Reconfigurations of Practice, Community, and Authority in Contemporary Aceh. 2016. Leiden: Brill, pp. 186

[34] Otto and Otto. Shari a Police in Banda Aceh, pp. 188

[35] Afrianty. Women and Sharia Law in Northern Indonesia, pp. 64.

[36] R. Idria. (2016). Muslim Punks and State Shari'a. In R. M. Feener, D. Kloos \& A. Samuels. (Eds.), Islam and the Limits of the State Reconfigurations of Practice, Community, and Authority in Contemporary Aceh. 2016. Leiden: Brill, pp. 251

[37] Afrianty. Women and Sharia Law in Northern Indonesia, pp. 74

[38] Afrianty. Women and Sharia Law in Northern Indonesia, pp. 97

[39] BBC News. Churches attacked and one man killed in clashes in Aceh, Indonesia - BBC News. (2015, October 14). Retrieved April 03, 2016, from http://www.bbc.com/news/world-asia34524817

[40] Afrianty. Women and Sharia Law in Northern Indonesia, pp. 74

[41] Afrianty. Women and Sharia Law in Northern Indonesia, pp. 76 